\title{
Peran Tokoh Agama dalam Menangani Penyebaran Covid-19
}

\section{Muchammadun Muchammadun ${ }^{*}$, Sri Hartini Rachmad ${ }^{2}$, Dendi Handiyatmo ${ }^{3}$, Ayesha Tantriana ${ }^{4}$, Eka Rumanitha5 ${ }^{5}$ Zaenudin Amrulloh ${ }^{6}$}

UIN Mataram, Indonesia; muchammadun@uinmataram.ac.id

Badan Pusat Statistik, Indonesia; shrachmat2@gmail.com

3 Badan Pusat Statistik Sulawesi Utara, Indonesia; denatmo@bps.go.id

4 Badan Pusat Statistik DKI Jakarta, Indonesia; ayesha@bps.go.id

Sekolah Tinggi Ilmu Statistik - Politeknik Statistik, Indonesia; eka.rumanitha@stis.ac.id

UIN Mataram, Indonesia; amrulloh@uinmataram.ac.id

* Correspondence

Received: 2020-12-01; Accepted: 2021-02-12; Published: 2021-05-25.

\begin{abstract}
This reseach examines the role of religious leaders in public health in the context of Covid19 management. There are two arguments in this study. First, in the context of a religious society, religious leaders can play a socio-religious role through public health education. Second, the role will be effective as religious leaders analyze the media for providing da'wah public health material in accordance with the characteristics of the population. This article uses a descriptive method of analysis, which systematically describes facts and factual data. The data is then processed in a descriptive way to show how a phenomenon works. The primary data collected are The BPS survey on Community members' behaviours on Covid-19 pandemic (BPS, 2020) and FGDs, analysed in the frame of related literature review. Results are reported in descriptive qualitative analysis. It is found that the community members' obidinece on the Covid-19 health protocol is well influenced by the roles of sosial media, religious leaders' suggestions, the population demographic characteristics and the enforcement of setup rules and policy.
\end{abstract}

Keywords: Covid-19 Pandemic; demography; health; Indonesia; religion.

Abstrak: Penelitian ini membahas peran tokoh agama dalam menangani penyebaran Covid-19 di Indonesia. Ada dua argumen dalam Penelitian ini. Pertama, pada konteks masyarakat yang agamis, tokoh agama bisa mengambil peran sosio keagamaan lewat pendidikan kesehatan masyarakat. Kedua, peran akan efektif jika tokoh agama menganalisis media penyampaian materi dakwah sesuai karakteristik penduduk. Artikel ini menggunakan metode analisis deskriptif, yang menguraikan secara sistematis fakta dan data secara faktual. Kemudian data diolah secara deskriptif untuk menunjukkan bagaimana suatu fenomena bekerja. Sumber data utama yang digunakan adalah hasil Survei Perilaku Masyarakat saat Covid-19 merebak (BPS, 2020), Focus Group Discussion (FGD) dan kajian literatur yang relevan. Penelitian ini menggunakan teori konstruksi social dari Peter L. Berger. Hasil penelitian menunjukkan bahwa tokoh agama bisa berperan sebagai agen sosial dalam pencegahan Covid-19 melalui kegiatan keagamaannya. Efektivitas peran tadi dipengaruhi oleh media sosial sebagai media, karakteristik demografi penduduk dan tegasnya peraturan -kebijakan yang diterapkan.

Kata Kunci: agama; demografi; Indonesia; kesehatan; pandemi Covid-19.

\section{Pendahuluan}

Merebaknya wabah Covid-19 telah mendorong terjadinya adaptasi baru dalam dimensi-dimensi kehidupan termasuk dalam praktik-praktik keagamaan di masyarakat. Adaptasi baru tersebut termasuk dalam penyelenggaraan kegiatan kehidupan sehari-hari, seperti penyesuaian jarak saat shalat berjamaah. Perilaku masyarakat demikian menuntut terjadinya perubahan proses pelaksanaan 
beribadah melalui efektivitas komunikasi di tengah masyarakat dalam menghadapi dan mengatasi krisis Covid-19. Pada konteks inilah peran tokoh agama menjadi penting. Karena, jika materi yang disampaikan kepada umat menjangkau tema kesehatan masyarakat dalam media yang tepat dan memperhatikan karakteristik umat, maka isu pandemi dan adaptasi ibadah yang merupakan masalah krusial dan sensitif dapat lebih dikomunikasikan secara efektif. Hal itu merupakan kebutuhan diseting masyarakat agamis dengan tipe mengikuti ucapan dan perbuatan tokoh agama. Muto, dkk. (2020), mengemukakan, masyarakat akan mengadopsi, meniru, mencontoh, dan mengamalkannya dalam kehidupan keseharian mereka dengan berdasarkan keyakinannya, bukan cukup dengan logika-pengetahuan.

Pengetahuan para pemangku kepentingan, khususnya tokoh agama, dalam praktik kehidupan keseharian menjadikan contoh sentral perilaku hidup sehat di tengah-tengah masyarakat saat krisis Covid-19. Berbagai aspek kehidupan masyarakat dituntut berubah secara cepat ketika menghadapi krisis Covid-19 (Agung, 2020). Sebagai tokoh sentral dan strategis dalam masyarakat, tokoh agama berkewajiban membantu upaya, turut hadir, dan berperan untuk memberikan data dan informasi terkait penanganan pandemi yang akurat dan terpercaya kepada masyarakat umum. Langkah dan tindakan cepat yang bersifat strategis dalam penanganan pandemik Covid-19 wajib segera diinformasikan dan sampai kepada masyarakat sebagai wujud komunikasi dan edukasi hidup sehat. Ini sangat membantu mengantisipasi untuk tidak tertular virus. Masyarakat dengan cepat dapat memahami prosedur yang perlu dilakukan jika sampai terinfeksi. Bahkan, diberlakukan Perda khusus dalam pelaksanaan pencegahan Covid-19 ini. Tim Garda Siaga Covid-19 juga turut dikerahkan hingga cakupan wilayah terkecil RT (Rukun Tetangga) untuk membendung timbulnya banyak korban.

Kasus meninggalnya Pastor dan keluarganya di Medan (Dewantoro, 2020) dan Bandung (Lazuardi, 2020) berikut terindikasi positif terinfeksi positif para anggota jamaahnya setelah dilakukan rapid test merupakan fakta para tokoh agama belum paham penularan Covid-19. Demikian juga perilaku para tokoh agama yang menghadiri perayaam keagamaan di India (Quadri, 2020), Tablig Akbar di Masjid Sri Petaling Malaysia (Yezli \& Khan, 2021), dan Gowa - Sulawesi Selatan (Aula, 2020) pada bulan Maret -April 2020 telah memperlihatkan perilaku keliru yang mendukung cepatnya penyebaran Covid-19 di masyarakat. Hal lain, banyaknya informasi asimetrik yang terjadi di media sosial, seperti: mengharamkan tidak sholat berjamaah di Masjid hanya karena pandemi Covid-19, hanyalah salah satu contoh fatal akibat informasi Hoax dan asymmetric information.

Untuk itu, perlu edukasi yang benar oleh para tokoh agama di masyarakat, sehingga para tokoh agama bisa menjadi role model yang efektif untuk menyebarkan contoh perilaku positif (Dutra \& Rocha, 2021; World Health Organization, 2020). Pentingnya peran para tokoh agama dan analisis mad'u dalam mengedukasi masa untuk berperilaku sesuai protokol kesehatan yang diberlakukan oleh pemerintah dalam mencegah krisis Covid-19 telah dikemukakan dalam temuan penelitian sebelumnya. Sebagai contoh, Aula (2020), mengemukakan kebutuhan itu, meskipun masih mempermasalahkan media komunikasi pesan sementara. Fahrurrozi (2018), bertitik fokus pada perubahan peran tokoh agama di seting masyarakat agamis Lombok. Penelitianini melengkapi celah pada analisis media dan pengaruh karakteristik penduduk untuk efektifitas penyampaian pesan dakwah tersebut.

Tokoh agama menjadi salah satu contoh figur sentral yang perilakunya dapat mengubah dinamika keadaan politik, sosial, agama. Peter L. Berger mengatakan bahwa tokoh agama berusaha memahami nilai-nilai keagamaan kemudian disosialisasikan kepada masyarakat. Tokoh agama tersebut sebagai agen sosialisasi (Berger \& Luckman, 1991, hal. 77). Hal tersebut sudah terjadi sejak lama, yaitu sejak zaman pra-kemerdekaan hingga masa sekarang yang berada pada era digital. Tokoh agama yang memiliki karisma sering menjadi sorotan. Perilaku, baik tindakan maupun ucapannya dapat dengan mudah tersebar dan diterima oleh masyarakat yang menjadi pengikutnya serta mayoritas di Indonesia. Terlebih pada saat ini, kemudahan penyebaran informasi lebih terasa dengan adanya media daring. Kemudahan ini kemudian dapat meningkatkan pengaruh dan peran tokoh masyarakat dalam mengontrol perubahan sosial-keagamaan (Aula, 2020). 
Tentu saja terdapat dua perubahan, yaitu perubahan yang bersifat positif dan perubahan yang bersifat negatif. Kemudahan yang diberikan dari adanya media daring kadang menimbulkan polemik sebagai akibat dari tidak disaringnya segala informasi, sehingga berita hoaks dan fakta tidak dapat dibedakan. Pasalnya, meskipun suatu berita benar atau salah, akan tetapi keberadaan tokoh agama notabene merupakan pelaku penting dalam pembentukan sikap masyarakat dinilai sebagai pemberi pernyataan yang benar. Seperti pada penelitian yang dilakukan Aula (2020), disebutkan, bahwa peran tokoh agama saat ini cukup vital dalam menghadapi perkembangan Covid-19, walaupun peran utama tetap dipegang oleh tenaga kesehatan. Eksistensi tokoh agama tidak dapat dipandang sebelah mata, khususnya dalam konteks Indonesia. Pengaruh tokoh agama di masyarakat akar rumput masih sangat kuat. Bahkan pada beberapa kondisi pengaruhnya lebih signifikan dibandingkan tenaga kesehatan sendiri. Hal ini dapat dilihat dari usaha pemerintah yang senantiasa melibatkan lembaga-tokoh agama dalam beberapa upaya menghadapi Covid-19.

Pernyataan di atas didukung juga oleh Fahrurrozi yang mengungkapkan, bahwa Tuan guru (tokoh agama) memainkan berbagai peran budaya dalam masyarakat. Ia tidak hanya sebagai pendidik dan penjaga budaya tradisional, tetapi juga sebagai mediator sosial (Fahrurrozi, 2018). Tuan guru tersebut biasanya lebih didengarkan dalam menyampaikan kebijakan yang ditetapkan oleh pemerintah. Menurut Daniel, bahwa peran tarbiyah pada umat Islam sebagai penduduk mayoritas menjadi penting dalam menangkal informasi spekulasi dan narasi konspirasi yang menjadi penghambat percepatan melawan Covid-19 (Tumpal, 2020). Oleh karena itu, peran tokoh agama sangat dibutuhkan demi menghambat penyebaran Covid-19 ini. Apalagi mengingat pengikut dari tokoh agama yang banyak dapat dikerahkan untuk melawan informasi yang asimetris pada kelompok minoritas yang tidak percaya Covid-19. Sehingga peran tokoh masyarakat tidak lagi hanya sebagai pendakwah, melainkan ikut serta sebagai pengembang masyarakat.

Namun, di Indonesia sendiri definisi tokoh agama yang representatif untuk diikuti ajarannya belum dapat diketahui secara pasti. Secara garis besar, pemahaman masyarakat Indonesia mengenai tokoh agama yang dijadikan role model masih sebatas mereka yang memiliki pemahaman atau keahlian dalam bidang agama dan memiliki banyak pengikut. Berbeda halnya dengan pendapat yang dikemukakan Azra (dalam Burhanudin, 2020), bahwa spesifikasi keahlian agama dalam masyarakat Indonesia yang dimaksudkan masih ambigu. Beberapa kalangan yang memiliki keahlian dalam bidang fiqh, terkadang masih dianggap sebagai seorang cendikiawan dibandingkan sebagai tokoh agama. Ketidakpastian inilah yang berdampak kepada masalah sosial-kemasyarakatan di Indonesia.

Dalam kasus penyebaran Covid-19 di Indonesia, bahwa pengaruh dari keberadaan tokoh agama sangat besar. Peran tokoh agama menuai kontroversi ketika pandemik mulai masuk di Indonesia. Konsep ketakwaan yang dipegang teguh oleh tokoh agama dijadikan tameng dan dianggap mampu memproteksi tubuh dari serangan musibah. Konsep ini pada awalnya menentang anjuran pemerintah mengenai pembatasan fisik/sosial untuk mencegah penyebaran Covid-19. Kebijakan pemerintah ini ditafsirkan oleh sebagian figur tokoh agama sebagai bentuk ketakutan terhadap penyakit (segala sesuatu) yang diciptakan Tuhan. Pernyataan mereka tak pelak memiliki kekuatan yang mutlak bagi sebagian kalangan dalam menjalani kehidupan beragama. Akan tetapi dari sudut pandang yang lain, dogma semacam itu, jelas menyebabkan kesadaran masyarakat akan penyebaran penyakit menjadi kecil. Adanya doktrin tersebut membuat masyarakat tidak takut terhadap penyakit, sehingga tingkat kewaspadaan menurun yang diikuti dengan semakin meluasnya penyebaran penyakit.

Dalam konteks wabah yang mengglobal, dibutuhkan sebuah Fiqh Pandemi yang mengatur ibadah umat Islam. Pakem yang telah ditatapkan ulama tentang ibadah yang tidak boleh membahayakan diri sendiri dan orang lain dapat dipilih sebagai dasar dalam menjalankan ibadah di zaman new normal sekarang, tentu saja tidak menyalahi aturan dan tidak menggugurkan pahala (Saenong, Zuhri, Hasan, \& Halimin, 2020). Apabila Fiqh Pandemi tersebut telah disetujui oleh para ulama, maka tokoh agama lain dan umatnya juga mampu menjalankan kebijakan yang ditetapkan oleh pemerintah sehingga dalam menjalani kegiatan keagamaan dilakukan dengan protokol yang 
ketat untuk menekan penyebaran pandemi, seperti strategi yang dilakukan oleh Syekh Al-Zaytun di Ma'had Al-Zaytun (Imam, Rohmah, \& Sunarya, 2020).

Selanjutnya, Saenong dkk (2020) juga mengingatkan, bahwa dalam menghadapi wabah penyakit yang menular sangat cepat ini, diperlukan persatuan dan kekompakan di bawah komando pemerintah. Pemerintah dengan masukan dan arahan dari tenaga dan ahli medis/kesehatan, telaah mendalam majelis ulama dari tinjauan keislaman, dan masukan pihak berkompeten lainnya merupakan jaminan yang harus dipatuhi. Akan tetapi perlu diperhatikan kembali, bahwa peran tokoh agama menjadi aktor utama dalam penyebar informasi. Hal itu sesuai dengan temuan lapangan yang dilakukan oleh Katadata Insight Center bersama Kementerian Komunikasi dan Informatika dan Gerakan Nasional Literasi Digital Siberkreasi dalam Survei Literasi Digital Nasional (2020) yang menemukan, bahwa responden menaruh kepercayaan tertinggi untuk informasi yang bersumber dari tokoh agama. Berdasarkan survei tersebut, sebanyak 50,6 persen menjawab percaya terhadap tokoh agama dan 34,7 persen yang menjawab biasa saja.

Metodologi yang digunakan adalah analisis deskriptif terhadap hasil penelitian kerja lapangan berupa FGD (Focus Group Discussion) sebagai data mikro dan penelitian kepustakaan. Artinya, data yang dikumpulkan berasal dari kerja lapangan dan dilengkapi dengan studi pustaka agar diperoleh analisis yang akurat dan terpercaya karena berdasarkan data sohih serta bisa dipertanggungjawabkan. Metode deskriptif analitis menurut (Arikunto, 1992; Kurniawan, Sohibien, \& Rahani, 2019; Sugiyono, 2009) adalah suatu metode yang berfungsi untuk mendeskripsikan atau memberi gambaran secara induktif terhadap objek yang diteliti melalui data atau sampel yang telah terkumpul sebagaimana adanya berupa table, grafik dan ringkasan numerik. Ditegaskan oleh Kurniawan, R., Gama P.D. S. \& Rini R. (Kurniawan et al., 2019), bahwa dalam analisis statistik deskriptip perlu dilakukan analisa dan penafsiran, meskipun tidak melakukan penarikan kesimpulan secara umum.

Sumber data mikro diperoleh dari FGD di dua propinsi, yaitu: Nusa Tenggara Barat (NTB) dan Sulawesi Utara (Menado) yang dinilai sebagai evidence base untuk menjawab bagaimana dan mengapa dari kebijakan aksi yang dilakukan di masyarakat. Pemilihan dua propinsi sebagai evidence base dengan pertimbangan purposive choice method dan diasumsikan bisa mewakili praktik aksi dua kelompok besar penganut agama yang ada di Indonesia, yaitu Islam dan Kristen. FGD dilakukan di pondok pesantren, masjid, dan gereja. Sumber data makro diperoleh dari hasil Survei Perilaku Masyarakat di Masa Pandemi COVID-19 yang dilakukan oleh Badan Pusat Statistik (BPS) selama kurun waktu satu minggu yang dimulai tangal 7 hingga 14 September 2020 secara online, mendapatkan respon sebanyak 90.967 responden yang mencakupi seluruh wilayah Indonesia.

\section{Pembahasan dan Diskusi}

Informasi asimetris, kemampuan tokoh memilih media penyampaian informasi, dan tokoh yang meyakini Covid-19 tidak ada membuat masih adanya sekelompok masyarakat yang belum mengetahui dan memahami jika Covid-19 itu ada dan benar-benar terjadi. Hal ini sangatlah memprihatinkan dan mengkawatirkan bagi pemerintah dan pihak-pihak lain terkait di dalamnya, karena pemahaman tadi berkontribusi pada penyebaran yang tinggi di masyarakat. Di sisi lain, risiko tingkat penularan/ infeksi yang tinggi akan diikuti banyaknya korban meninggal dengan sebab sepele, yaitu ketidakpercayaan atas Covid-19. Pemikiran tidak percaya akan adanya wabah dan makhluk Covid-19, bisa dimungkinkan karena beberapa hal: abai, tidak punya akses pengetahuan, kepercayaan yang kuat bahwa YME menciptakan makhluk hidup untuk kepentingan dan kebutuhan umatnya sehingga tidak perlu takut, mendapatkan pengetahuan dan informasi yang dari sumber yang salah, tidak punya info yang akurat, hanya hoax yang sering diperoleh, salah referensi. Sehingga, meskipun kebijakan pembatasan sosial berskala besar (PSBB) dan adaptasi kebiasaan baru dilakukan oleh pemerintah sebagai upaya untuk memutus persebaran virus corona. Kebijakan tersebut mendorong masyarakat untuk menyesuaikan perilaku sesuai dengan protokol kesehatan yang ditetapkan oleh pemerintah. Kelompok masyarakat yang bersikap dan perilaku seperti ini nampaknya akan 'tidak berpengaruh' terhadap nalar dan pikirnya. Untuk itu diperlukan tokoh-tokoh 
penting yang ada di masyarakat yang bisa ditempatkan sebagai garda terdepan, untuk mengkomunikasikan dan melakukan edukasi yang benar kepada masyarakat perihal adanya Covid19 yang berbahaya bagi kesehatandan penyelamatan jiwa mereka. Sedangkan merujuk hasil survei perilaku Covid-19 (BPS Statistics Indonesia, 2020) menyatakan bahwa dari observasi big data,

...kata kurang dan kesadaran menjadi kata yang paling sering digunakan untuk alasan tidak menerapkan protokol kesehatan lainnya....... Sebanyak sekitar 17 persen dari seluruh respon responden menyatakan tidak ada kemungkinan tertular....

Tokoh sentral dan strategis dalam masyarakat, yaitu tokoh agama berkewajiban penuh membantu upaya Pemerintah untu memberikan dan menyebarkan ilmu pengetahuan, data dan informasi terkait penanganan pandemi Covid-19 yang mudah dipahami, akurat, dan terpercaya kepada masyarakat beragama. Sebagai bukti, hasil survei perilaku BPS (2020) menunjukkan, bahwa; masyarakat cenderung menggunakan Media Sosial, Televisi, dan Whatsapp sebagai media terpopuler untuk memperoleh informasi mengenai perilaku hidup sehat, memahami protokol kesehatan berlaku dan pentingnya mencegah penyebaran Covid- 19. Informasi dan edukasi terkait protokol kesehatan dan urgensi pencegahan penyebaran Covid-19 melalui perubahan perilaku di masyarakat yang di sampaikan oleh Tokoh agama dan masyarakat hanya mencapai 40,7 persen, Medsos 83,6 persen, Televisi (TV) 78,5 persen, Whatshapp 76,1 persen, Media online/ daring 66,1 persen, Poster dan baliho 60,5 persen, Informasi Pemda 59,2 persen, chatapp lainnya 39,0 persen, rumah ibadah 34,7 persen, surat kabar 31,8 persen dan radio 24,8 persen. Kita semua tahu media sosial kita di Indonesia sangat penuh dibanjiri oleh informasi yang bersifat hoax, sehingga masyarakat perlu berhati-hati dalam memilih, memahami dan mengakses berita dan informasi dari Medsos (Media Sosial). Demikian juga Kemenkominfo, berkewajiban menyeleksi dan memberikan pemahaman kepada masyarakat akan pengetahuan penelusuran data-fakta dan informasi yang akurat dan terpercaya. Dilaporkan adanya tiga media terbesar yang paling disukai masyarakat dan sangat berpengauh dalam mengangtisipasi penyebaran Covid-19, yaitu: 34,05 persen 'Media Sosial', 23,72 persen 'Media Televisi' dan 12,30 persen melalui 'Whatsapp' di bandingkan media lainnya (Daring, poster, Info Pemda, Tokoh agama/ Toma, Rumah ibadah, Surat kabar dan radio).

\section{Tindakan Masyarakat Jika ada yang Terinfeksi}

Masyarakat memberikan respons aksi yang berbeda-beda jika ada orang di sekitar lingkungan berada ada yang terinfeksi Covid-19. Dari hasil survei perilaku Covid-19 (BPS. 2020), melaporkan bahwa, tindakan yang paling banyak dilakukan warga dan masyarakat adalah memperketat protokol kesehatan di lingkungan (45 persen), memberikan dukungan (22 persen), Mengucilkan/ stigmatisasi negative ( 7 persen) dan ada sebanyak ( 2 persen) yang tidak perduli.

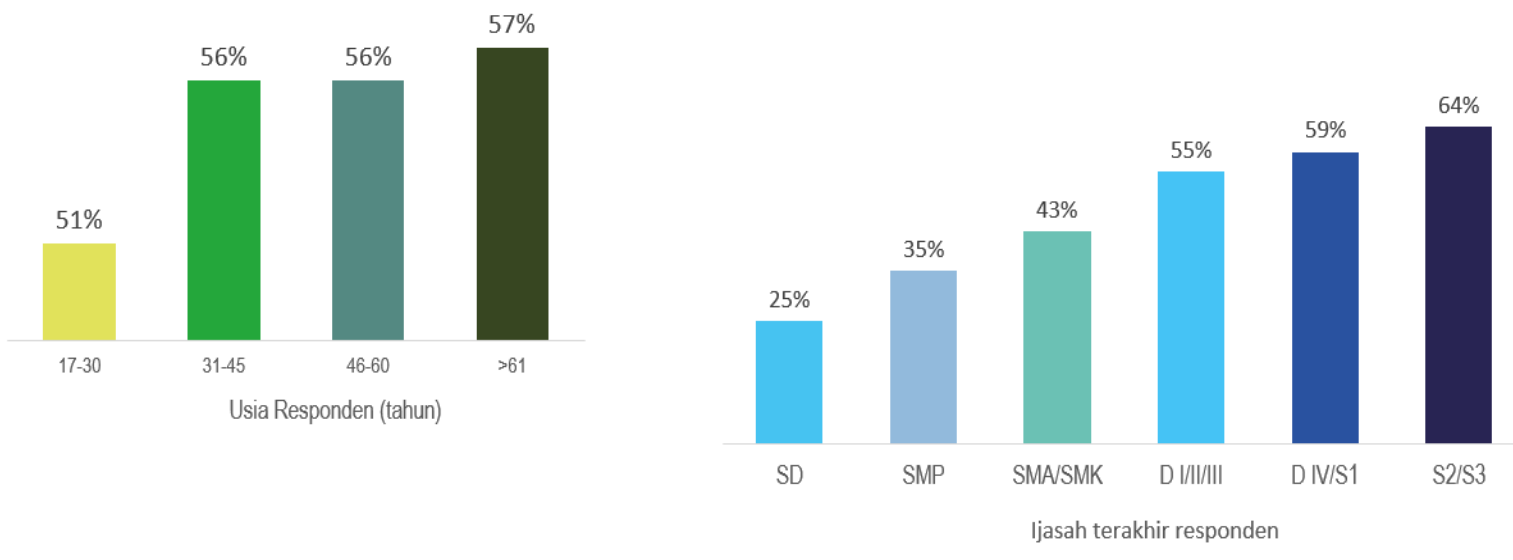

Gambar 1 Menurut usia dan pendidikan terakhir responden (BPS 2020) 
Laporan survei (BPS, 2020) memperlihatkan bagaimana pengaruh pengetahuan sangatlah kuat terhadap perilaku positip dan mendukung protocol Kesehatan yang diberlakukan di masyarakat. Demikian juga untuk orang dewasa yaitu kelompok usia 30 tahun ke atas, yang bisa di asumsikan usia dewasa dan berpengetahuan, maka memiliki respons yang positif juga (gambar 1).

Sementara itu, bila di tinjau dari masyarakat 'Tidak menerapkan protokol kesehatan', ditemukan Lebih dari setengah (50 persen) responden berpendapat bahwa tidak ada sanksi menjadi alasan utama masyarakat untuk tidak menerapkan dan mengikuti protokol kesehatan yang sedang diberlakukan (Gambar 2). Pada bar chart ini, 90.967 total responden yang disurvey bisa memilih lebih dari satu kriteria, mengikuti Mathematical subset diagramme Venn.

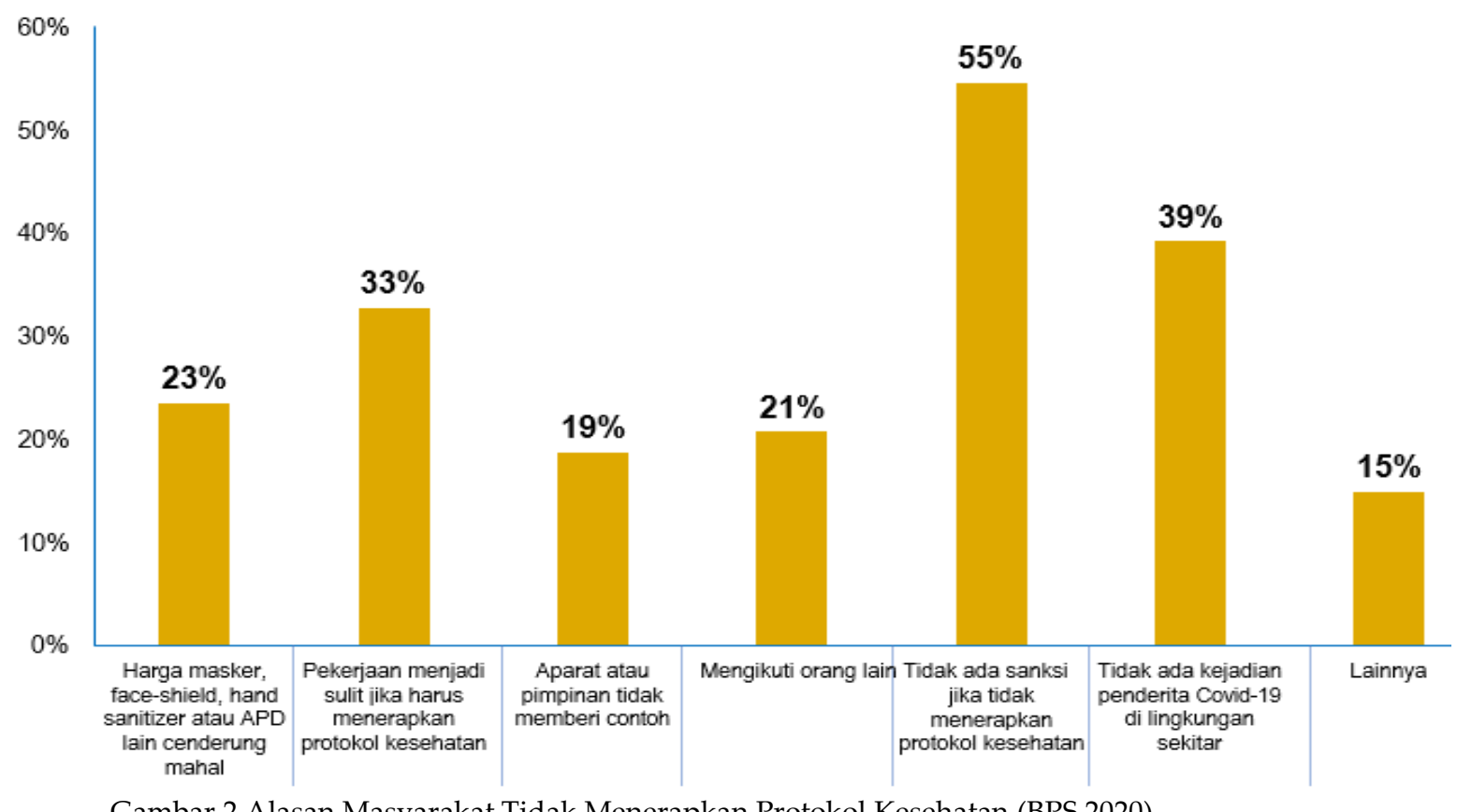

Gambar 2 Alasan Masyarakat Tidak Menerapkan Protokol Kesehatan (BPS 2020)

Pada gambar 2, alasan tidak mematuhi protokol kesehatan yang ada, yang didominasi oleh contoh pimpinan dan tokoh panutan di sekitar, yaitu: Aparat atau pimpinan tidak memberi contoh, masih sangat besar persentasenya 19 persen. Dalam hal ini , jika kita piker dan bandingkan dengan peran dan contoh khusus perilaku Tokoh agama (tokoh agama) di masyarakat, maka kemungkinan akan memberikan dampak yang lebih besar lagi bagi masyarakat yang agamais. Mengingat kepatuhan terhadap seorang imam, yaitu tokoh agama adalah bersifat fanatisme.

\section{Opini Masyarakat Menurut Demografi}

Secara karakteristik demografi, dilaporkan bahwa tidak ada perbedaan pilihan yang nyata antara laki-laki (45 persen) dan perempuan ( 55 persen) dalam mematuhi protokol kesehatan yang diberlakukan dalam masyarakat. Semakin tinggi tingkat Pendidikan dan semakin tua, maka memiliki kecenderungan semakin patuh mengikuti protokcol Kesehatan yang diberlakukan. Menurut tingkat Pendidikan gambar 1 memperlihatkan tingginya persentase opini responden dari hasil survei perilaku Covid-19, menurut tingkat pendidikan yang ditamatkan dan kelompok umur dilaporkan bahwa alasan 'ketiadaan sangsi dan denda' menyebabkan masyarakat kurang/ tidak menerapkan protokol kesehatan dalam perilaku kehidupannya sehari-hari. Masyarakat yang berusia muda cenderung abai terhadap kepatuhan paeraturan dan protokol Kesehatan yang diberlakukan di masyarakat, sehingga membuat angka tingkat infeksi usia muda paling tinggi. 


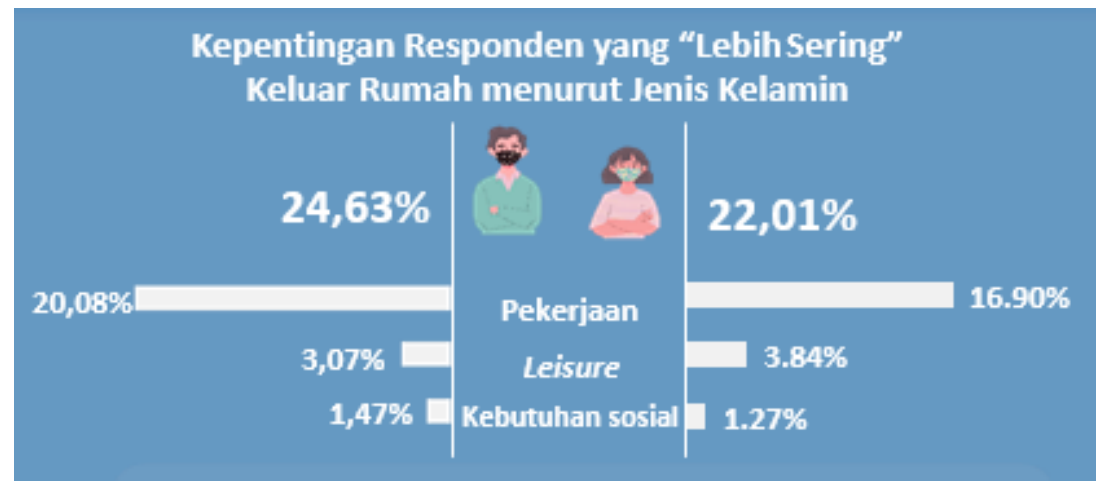

Gambar 3 Alasan Masyarakat Sering Keluar Rumah (sumber BPS 2020)

Persentase responden wanita yang lebih sering keluar rumah ternyata adalah untuk kesenangan, sedangkan bagi kaum pria memiliki alasan yang lebih rasional, yaitu; bekerja. Fakta hasil survei BPS ini menunjukkan bahwa mayoritas perempuan di Indonesia adalah ibu rumah tangga dan berada di rumah, sebaliknya pria sebagai tulang punggung keluarga, berkewajiban penuh menangung biaya hidup keluarga adalah wajib hukumnya untuk bekerja. Sementara itu, mobilitas dan alasan ke luar rumah ini akan memicu tiingginya penyebaran kasus infeksi di masyarakat. Perubahan kondisi masyraakat dalam berperilaku secara jenis kelamin sebagai perbedaan, memperlihatkan sangat nyata distribusinya, tujuan dan efeknya.

Merujuk pada Gambar 1 dan 3 secara analisa demografi memperlihatkan, bahwa masyarakat berusia tua dan berpendidikan tinggi, yang diasumsikan berpengetahuan cukup dalam berperilaku hidup sehat di masa pandemi Covid-19 memiliki kecenderungan lebih patuh terhadap PSBB dan peraturan lain yang diberlakukan serta berperilaku lebih hati-hati dan waspada dibandingkan dengan kelompok usia muda. Di sisi lain kaum wanita memiliki kecenderung kekawatiran tertular yang jauh lebih tinggi di bandingkan dengan kaum pria pada berbagai kelompok umur yang sama. Temuan ini sejalan dengan hasil riset yang dilakukan di Jepang (Muto et al., 2020)

\section{Aksi dan Tindakan Tokoh Agama}

Merujuk hasil Survei perilaku masyarakat menanggapi pandemi Covid-19 yang dilakukan oleh BPS tahun 2020, dilaporkan terdapat 5,78 persen responden dari 90.967 total responden memberikan jawaban opini di nilai akurat, mengakui bahwa tempat ibadah yang dikunjunginya tidak menerapkan protokol kesehatan sama sekali. Opini absennya protokol kesehatan di tempat ibadah ini merupakan persentase tertinggi sesudah 'pasar tradisional dan pedagang kaki lima' yaitu 17,3 persen. Tempat umum lainnya sebagai pembanding dari tempat ibadah, yaitu : mall/ plaza/ tempat perbelanjaan modern, pelayanan publik (transportasi umum, terminal, angkutan on-line) dan tempat bekerja (perkantoran). Sedangkan jenis tindakan aksi pencegahan dalam penerapan protokol kesehatan di tempat ibadah dibandingkan dengan tempat-tempat lainnya : 72,62 persen 'wajib menjaga jarak'; 85,69 persen 'Menggunakan masker'; 75,23 persen 'Mencuci tangan'; dan 41,85 persen ‘Pemeriksaan Thermogun'.

Mematuhi protokol kesehatan dalam upaya mencegah penularan Covid-19 merupakan suatu keharusan yang dilakukan oleh masyarakat melalui kebijakan yang muncul dari pemerintah pusat, pemerintah daerah, dan bahkan bisa muncul dari para tokoh tertentu (tokoh agama atau tokoh politik). Terlepas dari peran positif sosial keagamaan seperti pengadaan dapur umum berbasis afiliasi organisasi keagamaan sebagai respon pukulan ekonomi masa pandemi, beberapa tokoh agama justru menunjukkan hal yang berseberangan dengan kebijakan pemerintah dalam melaksanakan pendidikan hidup sehat di era pandemi. Dalam konteks manajemen Covid-19, sejumlah potensi cluster penularan Covid-19 di Indonesia, terkait dengan praktik sosial keagamaan. Praktik ini mulai dari perkumpulan jemaah di Gowa, 19-22 Maret 2020, yang terpaksa harus dibatalkan oleh aparat di tengah berdatangannya Jemaah. Selanjutnya, pertemuan keagamaan di Gowa tersebut disambung 
dengan himbauan penundaan pentahbisan tokoh keagaamaan yang melibatkan ribuan Jemaah di masa pandemi di Ruteng, Flores, Nusa Tenggara Timur 19 Maret 2020. Praktik terkini yang berpolemik adalah penjemputan kepulangan agamawan yang menimbulkan pelanggaran kerumunan atas protokoler Covid-19, 10 November 2020 lalu, serta himbauan pembatasan jemaah secara ketat pada perayaan hari besar keagamaan di tempat ibadah di Bogor dan Cimahi, 25 Desember lalu.

Menimbang peran agama dalam manajemen Covid yang bisa berdampak positif maupun negatif ini, strategi sosial keagamaan, dengan tindakan percontohan dari tokoh agamanya, terutama pada wilayah-wilayah yang kuat kehidupan sosial keagamaannya menjadi perlu dipetakan. Mengingat praktik sosial keagamaan dan manajemen Covid-19 bersifat lintas agama, pemetaan strategi tadi difokuskan pada dua wilayah yang kuat kehidupan sosial keagamaan Katolik dan Islamnya. Manado dan Mataram (NTB) dipilih sebagai studi untuk melihat strategi dan tanggapan sosial keagamaan terhadap kesehatan masyarakat di masa pandemi. Dari hasil FGD yang dilakukan di kedua propinsi yang menjadi perhatian peneliti, ditemukan praktik kebijakan lokal dan strategis, serta tanggapan sosial keagamaan terkait dua proporsi penganut agama terbesar dalam antisipasi penyebaran pandemi Covid-19 di Indonesia.

Pemberdayaan masyarakat dan tindakan aksi yang dimotori oleh tokoh agama Nasrani yang terjadi di ibukota Manado, yang sekaligus merupakan cerminan dari kebijakan lokal, antara lain: bentuk kegiatan ibadah tidak lagi dilakukan dengan cara biasa ada pembatasan durasi waktu ibadah, pembatasan usia untuk masuk gereja maupun pembatasan jumlah jemaah dalam jadwal waktu yang ditentukan dalam rangka social distancing, termasuk peyampaian ibadah yang dilakukan dengan cara live streaming yang muncul sebagai adaptasi pencegahan pandemi covid-19. Secara masal di berlakukan rapid test dan swab hampir di semua tempat ibadah pemeluk agama Kristen, dan Katolik, yaitu Gereja. Para pastur dan pendeta memimpin langsung di setiap kegiatan, disamping melakukan monitoring dan evaluasi terhadap anggota jama'ah yang berpartisipasi aktif dan non-aktif. Untuk memperluas jangkauan terlaksananya rapid test Covid -19 dan pembekalan pengetahuan mengantisipasi penularan Covid-19 di wilayah masing-masing, para tokoh agama Nasrani tak sungkan-sungkan turun langsung (turba) ke masyarakat. Kegiatan sosialisasi, komunikasi dan edukasi masyarakat yang dilakukan secara langsung ini sangat positip dampaknya dan membuat masyarakat meningkat kesadarannya akan 'dampak dan bahaya covid-19' jika terinfeksi, disertai juga pembekalan pengetahuan akan cara-cara mengenali gejala dan mengatasinya jika terinfeksi.

Tak kalah pentingnya, disamping mensyiarkan keagamaan, pengetahuan hidup sehat, para pemimpin dan tokoh agama Kristen dan Katolik yang ada di kota manado, juga membantu meringankan beban ekonomi yang di hadapi masyarakat. Kegiatan langsung yang berupa program desa membangun melaui relawan desa tanggap Covid-19 dari program Kemendes dengan slogan Membangun dari bawah dan pinggiran Bersama dengan Tokoh agama, menyalurkan bantuan dana Desa di tempat-2 ibadah. Dengan terciptanya SDGs Desa di Indonesia sejak 2019, yaitu: 'Desa peduli kesehatan', 'Desa peduli lingkungan' ; dan 'Desa tanpa kemiskinan dan kelaparan' ; maka para Tokoh agama bersama para pemangku kepentingan wilayah setempat yang terkait bersama-sama menyalurkan bantuan sosial maupun melakukan KIE kepada masyarakat terkait pencegahan penebaran Covid-19.

Kasus pertama warga NTB yang positif Covid-19 muncul dari seorang perempuan berusia 50 tahun (baca laporan Tempo, 24 Maret 2020) sebagai gelombang awal kecemasan warga NTB akan penularan virus kemudian gelombang yang lebih besar muncul dari kepulangan ratusan jamaah tablig asal NTB yang menghadiri Ijtima Zona Asia 2020 di Kabupaten Gowa. Jamaah asal NTB yang datang ke Gowa mencapai 700 orang (Lombok Post, 2020)Melakukan tracking 1 orang yang terpapar Covid-19 tentu lebih mudah daripada 700 orang. Sehingga kasus jamaah tablig tentu membutuhkan fokus yang lebih besar dan kebijakan yang serius dalam penanganan awal merebaknya Covid-19 di NTB.

Pemberdayaan masyarakat muslim di NTB pada masa pendemi Covid-19 tentu tidak jauh berbeda dari apa yang datang dari Pusat (kebijakan negara). Hal yang paling menonjol adalah 
manajemen masjid khususnya terkait dengan penggunaan fasilitasnya sebagai tempat shalat berjamaah. Misalnya, penggantian shalat Jumat dengan salat Zuhur yang sesuai dengan Fatwa MUI Nomor 14 Tahun 2020 tentang Penyelenggaraan Ibadah dalam Situasi Terjadi Wabah Covid-19. Jajaran pemerintah daerah baik pemerintah provinsi, kabupaten, hingga kota memiliki kebijakan yang sama terkait pelaksanaan shalat berjamaah di masjid.

Namun peran tokoh agama dalam memberikan wacana terkait pendidikan masayarakat akan perilaku hidup sehat di era pendemi Covid-19 seringkali alpa dari telinga masyarakat NTB. Hal ini pernah diungkapkan oleh Bupati Lombok Barat H. Fauzan Khalid, "Terutama para tuan guru yang menjadi panutan masyarakat sekiranya mereka diberikan penjelasan bahaya Covid-19 dengan cara penularannya, saya yakin pendapat mereka akan sama (tentang ibadah salat Jumat), karena sebenarnya ilmu agama (sumber ajaran) mereka sama". Absennya peran tokoh agama di NTB terkait pendidikan hidup sehat (hifzun nafs) di era pandemi mengakibatkan sempitnya kesadaran masyarakat akan mematuhi kebijakan yang menyelamatkan hajat dan hidup orang banyak.

Dakwah Islam tidak selamanya terikat dalam retorika-retorika konvensional, seperti: berhenti di dalam pembahasan halal dan haram, takfiri, atau tata cara peribadatan. Dakwah TGB (Tuan Guru Bajang) terkait Covid-19 (Lukihardianti, 2020) memberikan angin segar bagi cara berpikir masyarakat NTB yang arus utama pemikirannya mengenai bagaimana dakwah harus mampu menumbuhkan harapan dengan menggunakan triologi Islam (dakwah, akhlak, dan hidayah) yang diiringi secara bersama dan tidak dipisahkan. Artinya bahwa dakwah tidak boleh dilepaskan dari akhlak dan hidayah, sebagaimana Islam yang lahir dengan visi rahmat bagi seluruh alam. Dan hal ini tentu membungkam pemikiran-pemikiran Islam yang kolot di tengah masyarakat NTB, meski sebagian kecil kelompok masih bersikeras mengenai pandangannya akan Covid-19 sebagai berita bohong. Namun hal itu tidak membuat kelompok yang lebih besar untuk terlena dalam pandangan misinformasi. Sebab, gagasan yang diterima luas adalah yang paling siap memenuhi suatu kebutuhan sosial (Kleden, 1987).

Melihat dari dua studi kasus di atas, yaitu: Manado dan Mataram membuktikan, bahwa adanya potensi dari tokoh agama untuk berperan menjangkau aspek kesehatan masyarakat di era pandemi Covid-19. Tokoh agama sebagai lembaga atau perorangan yang memilki daya doxa atau logika kepercayaan (dalam pengertian oleh Pierre Bourdieu, baca Jenkins, 2016: 100, 241-242) dipandang mampu melakukan eksternalisasi perilaku dan kepercayaan publik akan hal yang bersifat sosial (keagamaan).

\section{Kesimpulan}

Kesimpulan dari hasil penelitian ini menunjukkan, bahwa peran tokoh agama dari penduduk dua mayoritas beragama Islam dan Kristen serta Katolik pada keduanya sangat mempengaruhi perilaku dan tatanan pencegahan penularan dan penyebaran Covid-19 di masyarakat. Apalagi didukung dengan adanya massive transformasi informasi melalui berbagai media komunikasi, berupa: televisi, radio, koran dan media sosial yang mengekspos himbauan dan contoh perilaku yang benar oleh para tokoh agama dalam masyarakat di saat pendemi. Penguatan dan penyebaran pengetahuan yang benar dalam mengantisipasi pandemi Covid-19 oleh tokoh central sangat nyata berpengaruh dan perlu di dukung adanya perlindungan hukum secara tegas dalam pelaksanaan, agar masyarakat patuh dan memiliki kesadaran tinggi akan bahaya virus covid-19. Antara lain dengan memberlakukan denda, hukuman sosial dan hukuman ringan lain yang merupakan konsekwensi jika tidak mentaati peraturan yang di berlakukan sesuai dengan karakteristik demografi. Selain itu, peran penting dari tokoh agama dalam model dakwah yang informatif dan mendidik memberikan dampak terhadap budaya hidup sehat masyarakat. Sehingga dakwah model transformatif ini sebagai bagian dari peran tokoh agama sebagai aktor perubahan sosial.

Penelitian ini merekomendasikan, bahwa perlu dibuat dan dibentuk Perda (Peraturan Daerah) khusus untuk menangani penyebaran Covid-19 sesuai dengan kondisi tingkat pandemi yang terjadi di suatu wilayah tertentu menurut: jenis lokasi aktivitas masyarakat, ragam kegiatan-pencegahan dan jenis-jenis konsekwensinya. Sehingga penanganan penyebaran penyakit akibat Covid-19 melalui 
perubahan perilaku masyarakat yang di pelopori oleh para pemuka/ tokoh agama akan sangat berlaku efektif dan efisien.

\section{Referensi}

Agung, I. M. (2020). Memahami Pandemi Covid-19 Dalam Perspektif Psikologi Sosial. Psikobuletin: Buletin Ilmiah Psikologi, 1(2), 68-84.

Arikunto, S. (1992). Prosedur penelitian: Suatu pendekatan praktik. Jakarta: Rineka Cipta.

Aula, S. K. N. (2020). Peran Tokoh Agama dalam Memutus Rantai Pandemi COVID-19 di Media Online Indonesia. Journal of Islamic Discourses, 3(1), 125-148.

Berger, P. L., \& Luckman, T. (1991). The Social Construction of Reality: A Treatise in the Sociology of Knowledge. London: Penguin Books.

BPS Statistics Indonesia. (2020). Laporan Hasil Survei Perilaku Masyarakat di masa Pandemi. Jakarta, Indonesia.

Burhanudin, J. (2020). Ulama Perempuan Indonesia. Jakarta: Gramedia Pustaka Utama.

Dewantoro. (2020). Uskup Medan dan 4 Pastor Positif Covid-19, Jemaat Diminta Periksakan Diri. Diambil dari Kompas website: https://regional.kompas.com/read/2020/07/20/11395741/uskup-medan-dan-4-pastorpositif-covid-19-jemaat-diminta-periksakan-diri

Dutra, C. C. D., \& Rocha, H. S. (2021). Religious support as a contribution to face the effects of social isolation in mental health during the pandemic of COVID-19. Journal of religion and health, 60(1), 99-111.

Fahrurrozi. (2018). Tuan guru and social change in Lombok, Indonesia. Indonesia and the Malay World, 46(135), 117-134. https://doi.org/10.1080/13639811.2018.1452487

Imam, P., Rohmah, S. N., \& Sunarya, F. R. (2020). Peran Preventif Pemimpin dalam Pencegahan Penyebaran COVID-19; Strategi Syaykh Al-Zaytun di Ma'had Al-Zaytun dan Kontribusinya terhadap Masyarakat Sekitar. Salam: Jurnal Sosial dan Budaya Syar-i, 7(5), 403-422.

Jenkins, R. (2016). Membaca Pikiran Pierre Bourdieu. Yogyakarta: Kreasi Wacana.

Kleden, I. (1987). Sikap Ilmiah dan Kritik Kebudayaan. Jakarta: LP3ES.

Kurniawan, R., Sohibien, G. P. D., \& Rahani, R. (2019). Statistik Analisis, Data \& Eksplorasi (Edisi Pert). Jakarta: Pernada Media Group.

Lazuardi, I. T. (2020). Pendeta di Bandung Meninggal Positif Corona, Pernah ke Bogor. Diambil dari Tempo website: https://nasional.tempo.co/read/1323876/pendeta-di-bandung-meninggal-positif-corona-pernah-kebogor

Lombok Post. (2020). Pulang dari Sulsel, Ratusan Jamaah Tablig Asal NTB Dikarantina di Asrama Haji. Diambil dari Lombok Post website: https://lombokpost.jawapos.com/ntb/26/03/2020/pulang-dari-sulsel-ratusanjamaah-tablig-asal-ntb-dikarantina-di-asrama-haji/

Lukihardianti, A. (2020, November). TGB: Dakwah Harus Tumbuhkan Harapan di Tengah Pandemi. Diambil dari Republika website: https://www.republika.co.id/berita/qk90cd396/tgb-dakwah-harus-tumbuhkanharapan-di-tengah-pandemi

Muto, K., Yamamoto, I., Nagasu, M., Tanaka, M., \& Wada, K. (2020). Japanese citizens' behavioral changes and preparedness against COVID-19: An online survey during the early phase of the pandemic. PLOS ONE, 15(6), e0234292. https://doi.org/10.1371/journal.pone.0234292

Quadri, S. A. (2020). COVID-19 and religious congregations: Implications for spread of novel pathogens. International Journal of Infectious Diseases, 96, 219-221. https://doi.org/10.1016/j.ijid.2020.05.007

Saenong, F. F., Zuhri, S., Hasan, H., \& Halimin, M. (2020). Fikih Pandemi: Beribadah di Masa Wabah. Jakarta: Nuo Publishing.

Sugiyono. (2009). Metode Penelitian Kuantitatif, Kualitatif dan R\&D. Bandung: Alfabeta.

Tumpal, D. (2020). Penguatan Tarbiyah Umat dan Kontribusi Islam Atasi COVID-19. Jurnal Alasma - Media Informasi dan Komunikasi Ilmiah, 2(1), 13-22.

World Health Organization. (2020). Practical considerations and recommendations for religious leaders and faith-based communities in the context of COVID-19: interim guidance, 7 April 2020. World Health Organization.

Yezli, S., \& Khan, A. (2021). COVID-19 pandemic: it is time to temporarily close places of worship and to suspend religious gatherings. Journal of travel medicine, $28(2)$, taaa065.

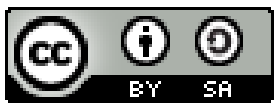

(C) 2021 by the authors. Submitted for possible open access publication under the terms and conditions of the Creative Commons Attribution (CC BY SA) license (https://creativecommons.org/licenses/by-sa/3.0/). 